\title{
P) Peertechz
}

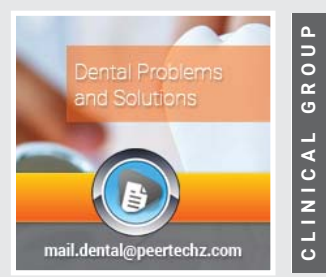

\section{Early treatment of anterior crossbite with eschler appliance: Two case reports}

\section{Kamila de Oliveira Novais Machado', Dauro Douglas Oliveira $^{2}$ and Andre Wilson Machado ${ }^{3 *}$}

${ }^{1}$ DDS, Graduate program in Orthodontics, Pontifical Catholic University of Minas Gerais, Belo Horizonte, Brazil

${ }^{2}$ DDS, MS, PhD, Associate Professor and Program Director of Orthodontics, Pontifical Catholic University of Minas Gerais, Belo Horizonte, Brazil

${ }^{3}$ DDS, MS, PhD, Associate Professor, Section of Orthodontics, Dental School, Federal University of Bahia, Salvador, Bahia, Brazil
Received: 08 July, 2020

Accepted: 13 July, 2020

Published: 15 July, 2020

*Corresponding author: Andre Wilson Machado, DDS, MS, PhD, Associate Professor, Section of Orthodontics, Dental School, Federal University of Bahia, Av. Araújo Pinho, $62-7^{\circ}$ Andar - Canela, Salvador, Bahia, Brazil, Tel: +55 713336 6973; E-mail: awmachado@gmail.com

Keywords: Orthodontics; Interceptive; Malocclusion; Malocclusion; Angle class III

https://www.peertechz.com

Check for updates

\section{Abstract}

Anterior Crossbite (AC) originates from skeletal alterations, functional, dental or their association, and may have genetic and/or environmental influences. Its prevalence varies between $2.2 \%$ and $12 \%$ depending on age, ethnicity and the type of AC. During the primary dentition, it varies between $4 \%$ and $7 \%$. The aim of this paper is to present two clinical cases of anterior crossbite correction in the primary dentition, in which the Eschler appliance was chosen for both treatments.

\section{Introduction}

Dentofacial disharmonies, especially in the sagittal plane, are of great interest among orthodontists, whereas the class III malocclusion occupies a prominent place. Clinically, in skeletal Class III malocclusions it is common to observe the presence of Anterior Crossbite (AC) in this type of malocclusion $[1,2]$.

AC originates from skeletal alterations, functional, dental or their association, and may have genetic and/or environmental influences. Its prevalence varies between $2.2 \%$ and $12 \%$ depending on age, ethnicity and the type of AC [3,4]. During the primary dentition, it varies between $4 \%$ and $7 \%$ [5-10].

It is important to intercept this malocclusion at the earliest time possible because the anterior interlock due to the AC could interfere in the maxillary growth and dental development, which can aggravate the class III disharmony. In such cases early interception is mandatory and the objective if to help establish a favorable environment for the growth of the maxilla $[3,4,9-15]$. However, one of the disadvantages of early interception is the difficulty in predicting long-term stability, as the ideal time for intervention is still a controversial issue, especially when AC is of skeletal origin $[16,17]$.

Several treatment modalities are used in the early interception of AC. Those vary between removable appliances associated with digital springs, fixed or removable inclined planes, functional devices, face masks and fixed orthodontic appliance $[1,6,7,9,10,12,15,17,18]$. However, there are few studies presenting the interception of this malocclusion in the primary dentition $[7,10,17]$. Due to the lack of clinical cases showing the correction of this malocclusion in the primary dentition and considering the importance of this correction at the earliest time possible, the publication of clinical cases is essential.

The aim of this paper is to present two clinical cases of anterior crossbite correction in the primary dentition, in which the Eschler appliance was chosen for both treatments.

\section{Case report}

\section{-Case $n^{\circ} 1$}

A female patient with 5-year 2-month old, was seeking 
orthodontic treatment because her parents complained about the AC. The medical and dental history showed no complications and her oral hygiene and gingival condition were within normal limits. The family did not report previous orthodontic treatments and no parental pattern of Class III malocclusion were observed or reported.

Facial evaluation showed slightly concave profile, absence of important asymmetries and presence of passive lip seal. In the intraoral evaluation, the following characteristic were found: the presence of complete primary dentition, midlines were even, second molars' distal relationship in mesial step and the presence of AC involving all incisors. In the evaluation of the discrepancy between Centric Relationship and Centric Occlusion (CR-CO), no functional deviation was observed (Figure 1: pretreatment intraoral photographs).

The panoramic radiograph showed the presence of all germs of the permanent teeth in different stages of maturation and absence of any pathology. Cephalometric analysis showed a developing Class III skeletal pattern (Figure 2: Pretreatment cephalometric radiograph and tracing; Table 1).

Treatment objectives were (1) to correct anterior crossbite and (2) provide a normal environment for the growth of the maxilla.

The treatment was performed through a Eschler appliance [2,17], which promotes basically dental effects by means of three characteristics: 1) digital springs: placed on the palatal side of the upper incisors to produce dental buccal movement; 2) anterior arch made of $0.8 \mathrm{~mm}$ stainless steel wire, surrounding the buccal surface of the lower incisors to promote lingual movement; 3) posterior acrylic plane: incorporated to reduce anterior overbite, allowing adequate buccal movement of upper incisors (Figure 3: Intra-oral frontal view of the appliance).

Patient and parents were instructed to remove the appliance only during meals and use it for as long as possible and at least for 14 hours per day. Activation started at the time of device's adjustment and activations of $1 \mathrm{~mm}$ per month were performed for 4 months, totaling a period of 5 months. After this period, the patient had a normal anterior relationship and after achieving an appropriate overjet, activations were discontinued. The same device was used in the retention phase for another 6 months.

After one year of follow-up, it was possible to observe improvement in facial profile, smile and slight decrease in ANB and Wits values found in the new cephalometric measurements (Table 1). Due to the possibility of relapse of Class III malocclusions, her parents were informed about
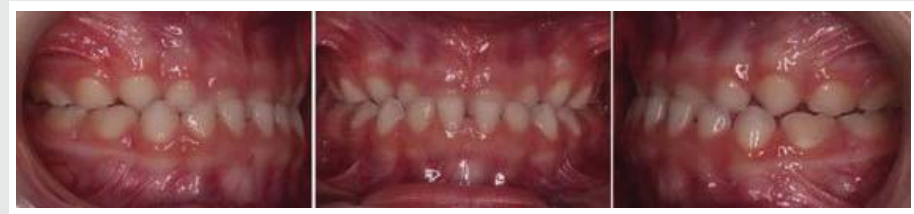

Figure 1: Pretreatment intraoral photographs.
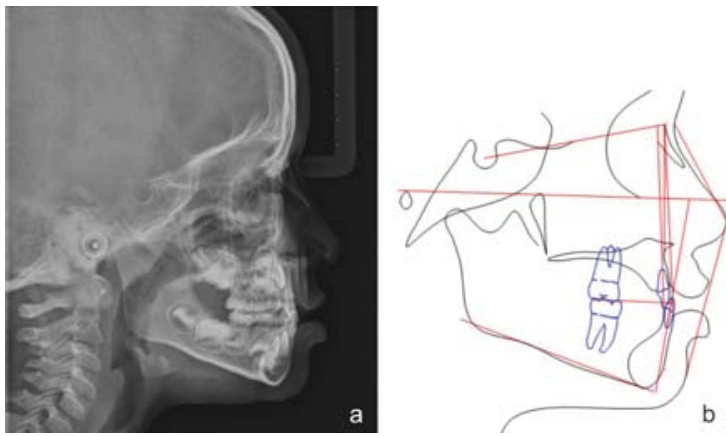

Figure 2: a) Pretreatment cephalometric radiograph; b) Pretreatment cephalometric tracing.

Table 1: Cephalometric measurements - before and after one year of treatment follow-up.

\begin{tabular}{|c|c|c|c|}
\hline Measurements & Norm & Pretreatment & 1-year follow-up \\
\hline SNA & $82^{\circ} \pm 2$ & $79.2^{\circ}$ & $82.1^{\circ}$ \\
\hline SNB & $80^{\circ} \pm 2$ & $82^{\circ}$ & $81.9^{\circ}$ \\
\hline ANB & $2^{\circ} \pm 2$ & $-2.8^{\circ}$ & $0.2^{\circ}$ \\
\hline Wits Appraisal & $0 \mathrm{~mm}-$ Women & $-3.9 \mathrm{~mm}$ & $-1.8 \mathrm{~mm}$ \\
\hline $1 . \mathrm{NA}$ & 22 & 15.8 & 18.9 \\
\hline $1 . N B$ & 25 & 23.1 & 23.9 \\
\hline 1.1 & 131 & 149.8 & 142.6 \\
\hline IMPA & $90 \pm 5$ & 87.5 & 88.8 \\
\hline
\end{tabular}

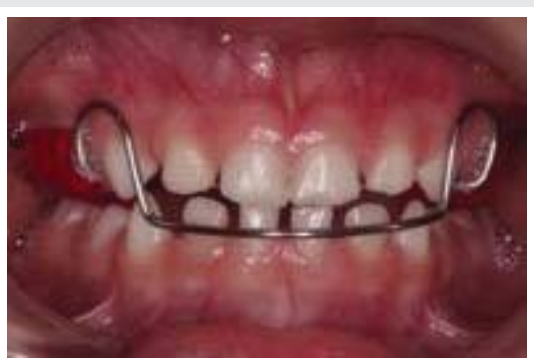

Figure 3: Intra-oral frontal view of the appliance.

the need of future consultations (Figure 4: 1-year follow-up intraoral photographs).

\section{- Case $n^{\circ} 2$}

A 4 years and 6 months male patient sought orthodontic treatment because there was a perception by his parents that he had an anterior crossbite. The medical and dental history did not present relevant data and his oral hygiene and gingival condition were in normal standards. There weren't reports of previous orthodontic treatments. No parental characteristics of Class III malocclusion were observed or reported.

Facial evaluation showed a slightly concave profile, no asymmetries and presence of passive lip seal. Patient presented in the primary dentition, coincident midlines, second molars' sagittal relationship in mesial step and presence of AC. In the evaluation of the CR-CO discrepancy, no functional deviation was observed (Figure 5: pretreatment intraoral photographs).

In the panoramic examination, no relevant data was observed. Cephalometric analysis showed a Class I skeletal 
pattern (Figure 6: Pretreatment cephalometric radiograph and tracing; Table 2).

Like the previous case, the treatment aimed early interception of the anterior crossbite. The treatment was performed with the same appliance previously described and under the same recommendations (Figure 7: Intra-oral frontal view of the appliance).

Activation was initiated at the time of device's adjustment and activations of $1 \mathrm{~mm}$ per month were performed for 5 months, totaling a period of 6 months. After this period, the patient had a normal anterior relationship and after achieving an appropriate overjet, activations were discontinued. In the retention phase, the same device was used for 7 months.

After one year of follow-up, improvement in facial profile, smile and good stability of the case could be observed. However, no significant cephalometric changes were found (Table 2), demonstrating maintenance of the same skeletal growth pattern. Aware of the great possibility of relapse in Class III malocclusion treatments, the parents were informed that the patient would remain under observation throughout their growth (Figure 8: 1-year follow-up intraoral photographs).

\section{Discussion}

Anterior crossbite is a well-established malocclusion in the literature. Several treatment modalities have been described, such as removable appliances associated with digital springs, fixed or removable inclined planes, functional devices, face
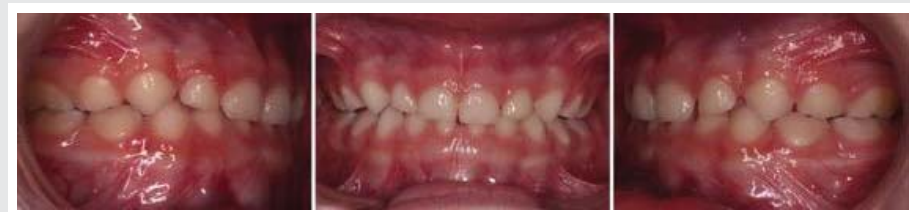

Figure 4: Results after 1-year follow-up.
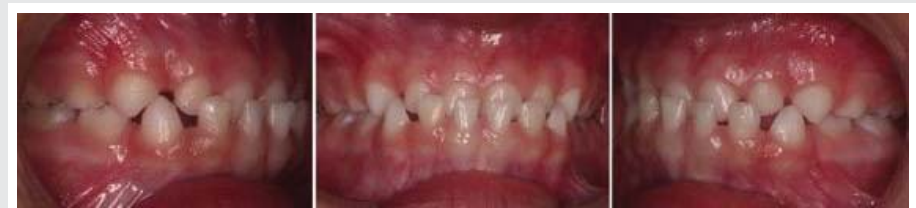

Figure 5: Pretreatment intraoral photographs.
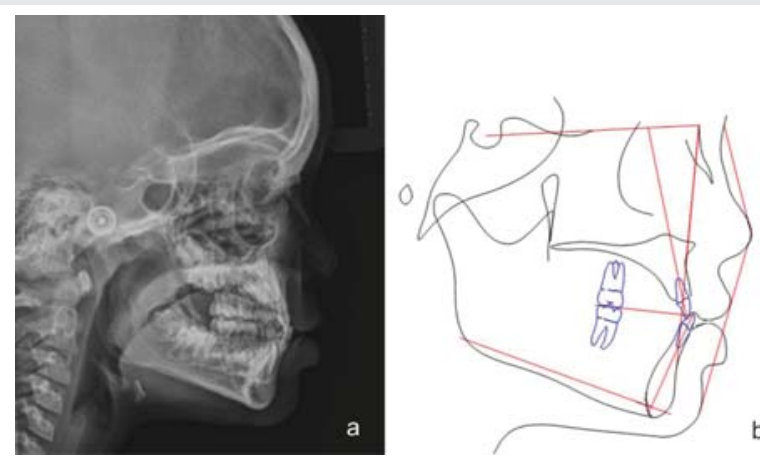

Figure 6: a) Pretreatment cephalometric radiograph; b) Pretreatment cephalometric tracing.
Table 2: Cephalometric measurements - before and after one year of treatment follow-up.

\begin{tabular}{|c|c|c|c|}
\hline Measurements & Norm & Pretreatment & 1-year follow-up \\
\hline SNA & $82^{\circ} \pm 2$ & $81.7^{\circ}$ & $82.9^{\circ}$ \\
\hline SNB & $80^{\circ} \pm 2$ & $81.9^{\circ}$ & $82.1^{\circ}$ \\
\hline ANB & $2^{\circ} \pm 2$ & $-0.2^{\circ}$ & $+0.8^{\circ}$ \\
\hline Wits Appraisal & $1 \mathrm{~mm}-$ Men & $-0.9 \mathrm{~mm}$ & $-1.1 \mathrm{~mm}$ \\
\hline $1 . \mathrm{NA}$ & 22 & 17.2 & 20.7 \\
\hline $1 . N B$ & 25 & 24.1 & 24.8 \\
\hline 1.1 & 131 & 144.2 & 136.6 \\
\hline IMPA & $90 \pm 5$ & 92.5 & 92.9 \\
\hline
\end{tabular}

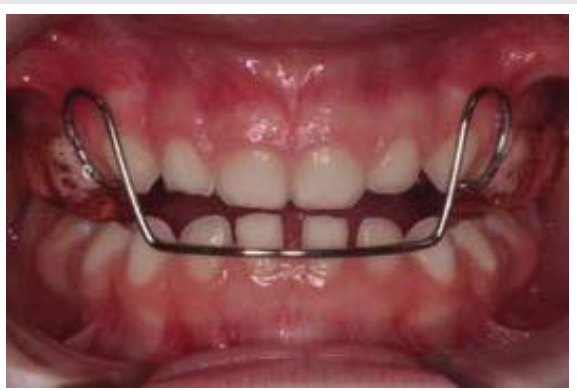

Figure 7: Intra-oral frontal view of the appliance.

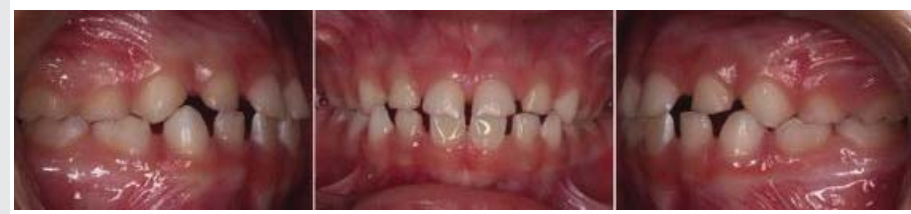

Figure 8: Results after 1-year follow-up.

masks and fixed orthodontic appliance $[1,6,7,9,10,12,15,17,18]$. In the cases described, it was decided to use an effective removable appliance called Eschler Appliance. At the end of treatment, favorable dental results, improvement in facial profile and short-term stability were demonstrated $[2,17,20]$. Although very effective in correcting dental AC during primary dentition [21], the Eschler appliance is limited to correct AC due to unfavorable skeletal sagittal growth as demonstrated in the cases presented.

When removable appliances associated with digital springs such as the Eschler appliance are chosen for the correction of $\mathrm{AC}$, literature reports an effective correction of the position of the upper incisors. In this cases, significant change in overjet and arch perimeter were observed, and when related to the significant increase in overbite during the post-treatment follow up, it is associated with even more stable results [3,18]. Studies showed that, when comparing the AC correction with fixed appliances, both present equally favorable stability and prognosis $[3,4]$.

After one-year follow-up, new cephalometric evaluation was performed. In case 1 , there was improvement in ANB and Wits. In case 2 , in contrast, small improvements were found. Cephalometric measurements show the dentoalveolar compensatory potential of the treatment, in which the 
upper incisors were moved buccally providing dentoalveolar remodeling [2]. However, because the corrections are only dentoalveolar, it makes the follow-up of patients who manifest $\mathrm{AC}$ in primary dentition indispensable in order to facilitate the second phase of treatment if necessary $[2,10,11,16,22]$.

Another problem encountered in AC associated with Class III skeletal patients is the long-term stability. Although literature shows encouraging results with facemask therapy1,10, great relapse tendencies are also found which points out that a consistent retention phase is needed as well as longer periods of follow-up [14]. In the case presented the same appliance was used as retention for $6-7$ months. According to the literature a positive overjet and overbite at the end of treatment appears to maintain the anterior occlusion [23]. On the other hand, since Class III patients grow similar to untreated Class III patients after treatment, the patients needs to be kept under observation till the time they pass the third growth spurt at 18 years of age [14].

Pediatric dentists are commonly the first professionals to be sought by parents for elucidation of AC in primary dentition. Proper diagnosis made by these professionals is essential due to the importance of early treatment, which goes beyond esthetic correction, prevents the worsening of the malocclusion, promotes a favorable environment for normal dentofacial growth and prevents the development of psychological problems and low self-esteem [2-4,9,11$14,16,17,22,23]$. Advantages such as reestablishing the position and normal activity of the perioral muscles, attenuation of the chances of developing temporomandibular disorders, correction of malocclusion-modified chewing and speech and the creation of a favorable environment for permanent incisors eruption also strongly support early intervention of AC in primary dentition $[3,4,7,10,17]$.

Lastly, to obtain favorable outcomes in early treatment of AC, it's essential to provide family guidance regarding the need and importance of patient and family adherence to the treatment. Also, the family should be warned about the uncertainty of long-term stability and the possibility of retreatments if unfavorable growth pattern occurs $[1,16]$. In such cases, when AC relapse occurs due to the unfavorable growth manifested by Class III malocclusion, the therapeutic approach of choice is to use the facial mask1,10 or skeletal anchorage [23].

\section{Conclusion}

The proper diagnosis associated with early treatment of anterior crossbite is decisive to achieve good occlusal and facial results, as well as reestablishing an appropriate psychological component for children. The use of the Eschler appliance represents a simple and effective option for the treatment of this condition while still in primary dentition.

\section{References}

1. Oltramari PVP, Garib DG, Henriques JFC, Conti ACCF, Freitas MR (2006) Tratamento ortopédico da Classe III em padrões faciais distintos. Rev Dent Press Ortod e Ortop Facial 10: 72-82. Link: https://bit.ly/305jbh3
2. Terada HH, Suguino R (1997) Utilização do Aparelho Progênico para Correção das Mordidas Cruzadas Anteriores. Rev Dent Press Ortod e Ortop Facial 2: 87 105. Link: https://bit.ly/32f7sPz

3. Wiedel AP, Bondemark L (2005) Stability of anterior crossbite correction: A randomized controlled trial with a 2-year follow up. Angle Orthod 85: 189-195. Link: https://bit.ly/3fuJZO7

4. Khalaf K, Mando M (2020) Removable appliances to correct anterior crossbites in the mixed dentition: a systematic review. Acta odontol. Acta Odontol Scand 78: 118-125. Link: https://bit.ly/20kcMJi

5. Bittencourt MAV, Machado AW (2010) Prevalência de má oclusão em crianças entre 6 e 10 anos - um panorama brasileiro. Dent Press J Orthod 15: 113-22. Link: https://bit.ly/3gYIB80

6. Abraham KK, James AR, Thenumkal E, Emmatty T (2016) Correction of anterior crossbite using modified transparente aligners: An esthetic approach. Contemp Clin Dent 7: 394-397. Link: https://bit.ly/2ZrHZR8

7. Devasya A, Ramagoni NK, Taranath M, Prasad KEV, Sarpangala M (2017) Acrylic Planas Direct Tracks for Anterior Crossbite Correction in Primary Dentition. Int J Clin Pediatr Dent 10: 399-403. Link: https://bit.ly/3fqjcm0

8. Vasilakos G, Koniaris A, Wolf M, Halazonetis D, Gkantidis N (2018) Early anterior crossbite correction through posterior bite opening: a 3D superimposition prospective cohort study. Eur J Orthod 40: 364-371. Link: https://bit.ly/3fERHpb

9. Kapur A, Chawla HS, Utreja A, Goyal A (2018) Guiding the Child's Teeth with Class III Dental Malocclusion into Correct Occlusion: A Clinician's Parenting Int J Clin Pediatr Dent 42: 72-78. Link: https://bit.ly/38Rye1R

10. Silva HCFP, Paiva JB, Neto JR (2018) Anterior crossbite treatment in the primary dentition: Three case reports. Int Orthod 16: 514-529. Link: https://bit.ly/2ZoCanC

11. Joondeph DR (1993) Early orthodontic treatment. Am J Orthod Dentofacia Orthop 104: 199-200. Link: https://bit.ly/2Wf5jzK

12. Hägg U, Tse A, Bendeus M, Rabie ABM (2004) A follow-up study of early treatment of pseudo class III malocclusion. Angle Orthod 74: 465-472. Link: https://bit.ly/20masS5

13. Kanno Z, Kim Y, Soma K (2007) Early correction of a developing skeletal Class III malocclusion. Angle Orthod 77: 549-556. Link: https://bit.ly/3j150XJ

14. Kapur A, Chawla HS, Utreja A, Goyal A (2008) Early class III occlusal tendency in children and its selective management. J Indian Soc Pedod Prev Dent 26 : 107-113. Link: https://bit.ly/32iOvvk

15. Almeida MR, Almeida RR, Oltramari-Navarro PVP, Conti ACCF, Navarro RL, et al. (2011) Early treatment of Class III malocclusion: 10-year follow-up. J Appl Oral Sci 19: 431-439. Link: https://bit.ly/2B03u28

16. Araújo EA, Araújo CV (2008) Abordagem clínica não-cirúrgica no tratamento da má oclusão de Classe III. Rev Dent Press Ortod e Ortop Facial 13: 128-157. Link: https://bit.ly/2B1LZ1u

17. Machado AW, Caldas SGR, Maia LGM (2016) Early correction of a developing Class III Malocclusion with a removable appliance. Dent Oral Craniofacial Res 2: 359-361. Link: https://bit.ly/30mB9vJ

18. Miamoto CB, Marques LS, Abreu LG, Paiva SM (2018) Comparison of two early treatment protocols for anterior dental crossbite in the mixed dentition: A randomized trial. Angle Orthod 88: 144-150. Link: https://bit.ly/3fESxCl

19. Jacobson A (1975) The "Wits" Appraisal of Jaw Disarmony. Am J Orthod 67: 125-137. Link: https://bit.ly/3fvbreO

20. Alhaija ESJA (2006) Skeletal, Dental and Soft Tissue Changes in Postura Class III Malocclusion Treated with a Maxillary Removable Appliance. J Clin Pediatr Dent 31: 149-152. Link: https://bit.ly/2C0ERD7 
21. Baccetti T, Tollaro I (1998) A retrospective comparison of functional appliance treatment of class III malocclusions in the deciduous and mixed dentition. Eur J Orthod 20: 309-317. Link: https://bit.ly/38WGYn6

22. Saadia M, Torres E (2000) Sagittal changes after maxillary protraction with expansion in class III patients in the primary, mixed and late mixed dentitions:
A longitudinal retrospective study. Am J Orthod Dentofac Orthop 117: 669680. Link: https://bit.ly/2DFt0Q6

23. Woon SC, Thiruvenkatachari B (2017) Early orthodontic treatment for Class III malocclusion: A systematic review and meta-analysis. Am J Orthod Dentofac Orthop 151: 28-52. Link: https://bit.ly/3eqYalW

\section{Discover a bigger Impact and Visibility of your article publication with}

\section{Peertechz Publications}

\section{Highlights}

* Signatory publisher of ORCID

* Signatory Publisher of DORA (San Francisco Declaration on Research Assessment)

* Articles archived in worlds' renowned service providers such as Portico, CNKI, AGRIS, TDNet, Base (Bielefeld University Library), CrossRef, Scilit, J-Gate etc.

* Journals indexed in ICMJE, SHERPA/ROMEO, Google Scholar etc.

* OAI-PMH (Open Archives Initiative Protocol for Metadata Harvesting)

* Dedicated Editorial Board for every journal

* Accurate and rapid peer-review process

* Increased citations of published articles through promotions

- Reduced timeline for article publication

Submit your articles and experience a new surge in publication services (https://www.peertechz.com/submission).

Peertechz journals wishes everlasting success in your every endeavours.

Copyright: ( 2020 Novais Machado KDO, et al. This is an open-access article distributed under the terms of the Creative Commons Attribution License, which permits unrestricted use, distribution, and reproduction in any medium, provided the original author and source are credited. 